\title{
Effect of Trihoney (A Mixture of Trigona, Mellifera and Tualang) on Male Reproductive Hormones and Insulin Resistance in Hypercholesterolaemic Rabbits
}

\author{
Hamad Mohamed $Z B^{a}$, Ibrahim $M^{a^{*}}$, Hamad Alfarisi $H A^{a}$, Abdul Wahab $A Y^{b}$, Abd Fuaat $A^{c}$, Che Mohamad $C A^{d}$ \\ ${ }^{a}$ Department of Nutrition Sciences, Kulliyyah of Allied Health Sciences, International Islamic University \\ Malaysia \\ ${ }^{b}$ Department of Obstetrics and Gynaecology, Kulliyyah of Medicine, International Islamic University Malaysia \\ 'Department of Pathology \& Laboratory Medicine, International Islamic University Malaysia Medical Centre \\ ${ }^{\mathrm{d}}$ Department of Basic Medical Sciences, Kulliyyah of Pharmacy, International Islamic University Malaysia
}

\section{ABSTRACT}

Introduction: Hypercholesterolaemia affects Sertoli and Leydig cells secretory functions, impairs steroid hormones biosynthesis, and disrupts the hypothalamic-pituitary-gonadal axis. The use of honey in previous studies resulted in an improvement of male reproductive hormonal disturbances. This study aimed to investigate the protective effects of Trihoney on hypercholesterolaemia-induced male reproductive hormonal changes in male rabbits and compare its effects with atorvastatin. Materials and methods: Fortyeight male New Zealand white rabbits were assigned into 6 groups as follows; Control: commercial pellet; $\mathrm{CH}$ : commercial pellet with $0.6 \mathrm{~g} / \mathrm{kg} /$ day Trihoney; HCD: $1 \%$ cholesterol diet; $\mathrm{DH} 1: 1 \%$ cholesterol diet with $0.3 \mathrm{~g} / \mathrm{kg} /$ day Trihoney; DH2: $1 \%$ cholesterol diet with $0.6 \mathrm{~g} / \mathrm{kg} /$ day Trihoney and DAt: $1 \%$ cholesterol diet with $2 \mathrm{mg} / \mathrm{kg} /$ day atorvastatin. After 12 weeks, the rabbits were sacrificed and blood samples were collected for analysis of hormones and pro-inflammatory cytokines and calculation of HOMA-IR. The testes were homogenized for intra-testicular testosterone measurement. Results: Serum testosterone reduced significantly in HCD $(p<0.05)$ and DAt $(p<0.05)$ groups. Likewise, intra-testicular testosterone reduced significantly in HCD $(p<0.01)$ and DAt $(p<0.01)$ groups. Serum FSH increased significantly in $H C D(p<0.001)$ and DAt $(\mathrm{p}<0.01)$. Trihoney particularly at the dose of $0.6 \mathrm{~g} / \mathrm{kg} /$ day improved serum and intra-testicular testosterone $(p<0.05)$ and FSH $(p<0.05)$. Trihoney and atorvastatin improved serum pro-inflammatory cytokines. Trihoney and atorvastatin did not affect HOMA-IR. Conclusion: Trihoney attenuated the detrimental effects of hypercholesterolaemia on male reproductive hormones which probably through a local effect on testicular tissue and Trihoney anti-inflammatory effect independent of insulin resistance. Atorvastatin did not counteract the impact of hypercholesterolaemia on the reproductive hormones.

KEYWORDS: Hypercholesterolaemia; Trihoney; Atorvastatin; Male reproductive hormones; Insulin resistance

\section{INTRODUCTION}

Testosterone is the principal male sex hormone secreted by Leydig cells in the testes. It is essential for testes development, spermatogenesis, and masculinization. Testosterone plasma level is a

Corresponding Author:

Assoc. Prof. Dr. Muhammad Bin Ibrahim

Postal address: Department of Nutrition Sciences, Kulliyyah of Allied Health Sciences, International Islamic University Malaysia, 25200 Kuantan,

Pahang, Malaysia

Tel no : +60139234998,

Email : abumaisarah@iium.edu.my useful indicator of testicular function. ${ }^{1}$ Inside Sertoli cells, testosterone is bound to androgen receptors. Activation of these receptors results in initiation and maintenance of spermatogenesis and prevents germ cells apoptosis. ${ }^{2}$ Follicle-stimulating hormone (FSH) and luteinizing hormone (LH) are secreted from the anterior pituitary gland and they are important for the normal male reproductive system. Folliclestimulating hormone stimulates spermatogenesis while LH triggers synthesis and secretion of androgens mainly testosterone. ${ }^{3}$ Previous studies have demonstrated a strong influence of dietary 
factors on testosterone with high-energy diet is one of the factors which may cause an imbalance in serum and intra-testicular testosterone. This imbalance was suggested to be due to the low level of insulin that negatively affects testosterone secretion. ${ }^{4}$ Systemic inflammation and overproduction of inflammatory cytokines are leading causes to the reduction of androgen production with subsequent disruption of spermatogenesis. Inconsistent results were reported about the effects of the high-energy diet and hypercholesterolaemia, whether it is associated with obesity or not, on the hormonal profile of the male reproductive system.

While some studies revealed an increase in testosterone, $\mathrm{FSH}$, and $\mathrm{LH},{ }^{5}$ others demonstrated a reduction in the levels of these hormones. ${ }^{4,6,7}$ On the other hand, the use of honey in previous studies resulted in an improvement of the male reproductive hormonal disturbances through increasing testosterone and reducing $\mathrm{FSH}$ and $\mathrm{LH}$ in rats fed with high sucrose diet and rats exposed to noise stress. ${ }^{8,9}$ Trihoney is a product developed by the Department of Nutrition Sciences of Kulliyyah of Allied Health Sciences of International Islamic University Malaysia. It is a mixture of Trigona, Mellifera and Tualang honey at a ratio optimized by Response Surface Methodology of Design Expert Version 6.0 software. This ratio produces the highest result of total phenolic content with consuming the minimum amount of each honey. Thus, the purpose of the current study was to investigate the protective effect of Trihoney on male reproductive hormonal changes induced by hypercholesterolaemia in male rabbits and compare its effect with atorvastatin as the most commonly used hypolipidaemic agent.

\section{MATERIALS AND METHODS}

\section{Animal}

Forty-eight male New Zealand white rabbits of 5months age were used in this study. Their environment was maintained under controlled conditions of $15-21^{\circ} \mathrm{C}$ temperature, $45-65 \%$ humidity, and 12 hours light/dark cycles. The rabbits were caged individually and provided free access to water and food. The animal handling procedures, treatment, and experimental protocols were approved by the International Islamic University Malaysia Institutional Animal Care and Use Committee (IACUC-IIUM), IIUM, Kuantan campus [No. of IACUC Approval: IIUM/IACUC Approval/ 2017/ (18) $-2]$.

\section{Preparation of $1 \%$ cholesterol diet}

One percent cholesterol diet was prepared according to the method of Mohamed et al., (2020). ${ }^{10}$ Ten grams of cholesterol powder (Nacalai-Tesque, Japan) were emulsified in $20 \mathrm{~mL}(2 \%)$ of coconut oil (Certified Organic, Philippines). The emulsion was then poured onto 970 grams of rabbit pellet and mixed thoroughly. It was repeatedly and freshly prepared twice weekly.

\section{Trihoney and atorvastatin doses}

Trihoney doses were calculated based on the conversion of human equivalent dose to rabbit equivalent dose according to the following equation: ${ }^{11}$

Human equivalent dose $\times$ Human $\mathrm{Km}$ factor $=$ Animal equivalent dose $\times$ Animal $\mathrm{Km}$ factor

The used dose of atorvastatin (Atorvastatin Winthrop ${ }^{\circ}$, Prague-Czech) was $2 \mathrm{mg} / \mathrm{kg} /$ day. ${ }^{12}$ Atorvastatin was reconstituted in $1 \mathrm{~mL}$ of distilled water then administered orally. ${ }^{13}$

\section{Experimental design}

After 2 weeks of acclimatization, the rabbits were assigned into 6 groups $(n=8)$ and received different diets as follows: 1) Control $(\mathrm{C})$ : commercial rabbit pellet, 2) $\mathrm{CH}$ : commercial pellet with a daily oral dose of $0.6 \mathrm{~g} / \mathrm{kg} /$ day Trihoney, 3) HCD: $1 \%$ cholesterol diet, 4) DH1: 1\% cholesterol diet with a daily oral dose of $0.3 \mathrm{~g} / \mathrm{kg} /$ day Trihoney, 5) DH2: $1 \%$ cholesterol diet with a daily oral dose of $0.6 \mathrm{~g} / \mathrm{kg} /$ day Trihoney, 6) DAt: $1 \%$ cholesterol diet with a daily oral dose of $2 \mathrm{mg} / \mathrm{kg} /$ day atorvastatin. Their weights were measured once weekly and the doses were adjusted accordingly. ${ }^{5}$ The duration of the experiment was 12 weeks.

\section{Animal sacrificing, blood collection and serum separation}

At the end of the 12 weeks, the rabbits fasted overnight and were euthanized using intramuscular injection of ketamine/ xylazine at a dose of 50/10 $\mathrm{mg} / \mathrm{kg}$ body weight followed by exsanguination. ${ }^{14,15}$ 
Blood samples were collected from the central ear artery for analysis of hormones (FSH, LH, and testosterone), fasting insulin, fasting blood glucose, and pro-inflammatory cytokines. The blood was allowed to clot at room temperature before centrifugation (Centrifuge Universal 320R, Hettich) at $3500 \mathrm{~g}$ and $4{ }^{\circ} \mathrm{C}$ for 15 minutes to separate the serum which was stored at $-80^{\circ} \mathrm{C}$ till the time of analysis. ${ }^{16-18}$ Fasting blood glucose and fasting insulin were measured using an automated analysis machine (AU 480 AU Analyser-Beckman Coulter, Inc. USA). Homeostatic model assessment of insulin resistance (HOMA-IR) was calculated using Matthews et al. $(1985)^{19}$ equation as follows:

HOMA-IR= Fasting serum insulin $(\mu \mathrm{U} / \mathrm{mL}) \times$ Fasting plasma glucose $(\mathrm{mmol} / \mathrm{L}) / 22.5$

\section{Testes harvesting}

Under clean conditions, a ventral midline incision was made through the abdominal cavity and pelvis to expose the internal organs. The left testis was allowed to be perfused with normal saline to clear it from the blood. ${ }^{20}$ Systemic perfusion was performed using ice-cold normal saline at a flow rate of 200 $\mathrm{mL} /$ minute through the left ventricular approach. The left testis was then excised, cut into pieces and preserved at $-80^{\circ} \mathrm{C}$ for homogenate preparation. ${ }^{21}$

\section{Preparation of testicular tissue homogenate}

Testicular tissue of each animal was weighed and homogenized to make $10 \%$ homogenate $(\mathrm{w} / \mathrm{v})^{22}$ in ice -cold phosphate buffer saline $(\mathrm{PBS})^{23}$ using Bullet Blender blue homogenizer (Next Advance, USA). Twenty microliters of protease inhibitor cocktail (Nacalai Tesque, Japan) was added to each testicular homogenate. The homogenate was then centrifuged in a refrigerated centrifuge (ThermoFisher Scientific, Germany) at $10000 \mathrm{~g}$ for 15 minutes at $4^{\circ} \mathrm{C}$. The obtained supernatant was stored at $-80^{\circ} \mathrm{C}$ and used for assaying of protein concentration and intratesticular testosterone.

\section{Protein assay in the testicular homogenate}

Protein concentration in the testicular homogenate was calculated to be used as a reference unit for the concentration expression of the assayed intra-testicular testosterone. It was measured using protein assay CBB solution assay kit (Ready to Use) from (Nacalai Tesque, Japan) according to the manufacturer's protocol. Albumin bovine serum (Nacalai Tesque, Japan) was used as a standard. ${ }^{22}$

\section{Analysis of hormones and pro-inflammatory cytokines}

Serum and intra-testicular testosterone, serum FSH and $\mathrm{LH}$ and serum interleukin (IL)-1B were estimated using Elisa kits from Cusabio Biotech, China. Serum IL -6 and tumour necrosis factor-alpha (TNF-a) were estimated using Elisa kits from Elabscience, China. The analysis was done according to the manufacturer's instructions.

\section{Statistical analysis}

Data were processed using the Statistical Package for the Social Sciences Version 21 (SPSS Inc., Chicago, Illinois, USA) program. They were expressed as means and standard deviations. One-way analysis of variance test (ANOVA) was used for data analysis followed by a post hoc test to determine any significant differences between the means of the independent groups. Differences were considered to be statistically significant at $p$ values less than 0.05 .

\section{RESULTS}

Effects of hypercholesterolaemia, Trihoney, and atorvastatin on serum and intra-testicular testosterone

Table I demonstrates the effects of hypercholesterolaemia, Trihoney, and atorvastatin on serum and intra-testicular testosterone. There was no significant difference between the $\mathrm{CH}$ group and the control in the serum and intra-testicular testosterone. Administration of $1 \%$ cholesterol diet either alone or in combination with atorvastatin showed a significant reduction in the serum $(p<0.05)$ and intra-testicular $(p<0.01)$ testosterone when compared to the control group. Trihoney received groups showed no significant difference from the control group in serum testosterone. The $\mathrm{DH} 1$ group was significantly lower than the control in intratesticular testosterone $(p<0.01)$. There was no significant difference between $\mathrm{DH} 2$ and the control group in intra-testicular testosterone. The $\mathrm{DH} 2$ exhibited higher levels of serum $(p<0.05)$ and intratesticular $(p<0.05)$ testosterone than the HCD group. 
Serum and intra-testicular testosterone were higher in DH1 than HCD and DAt groups but no significant difference was detected among them. The $\mathrm{DH} 2$ group expressed a significantly higher level of intratesticular testosterone than the DAt group $(p<0.05)$. There was no significant difference between $\mathrm{DH} 1$ and $\mathrm{DH} 2$.

Table I: Effects of hypercholesterolaemia, Trihoney and atorvastatin on serum and intra-testicular testosterone levels

\begin{tabular}{ccc}
\hline $\begin{array}{c}\text { Hormones } \\
\text { Groups }\end{array}$ & $\begin{array}{c}\text { Serum } \\
\text { testosterone } \\
(\mathrm{ng} / \mathrm{mL})\end{array}$ & $\begin{array}{c}\text { Intra-testicular } \\
\text { testosterone } \\
(\mathrm{ng} / \mathrm{mg} \text { protein })\end{array}$ \\
\hline C & $6.23 \pm 0.87$ & $0.34 \pm 0.02$ \\
CH & $6.66 \pm 0.85$ & $0.35 \pm 0.01$ \\
HCD & $2.28 \pm 1.90^{\mathrm{a}^{*}}$ & $0.26 \pm 0.05^{\mathrm{a}^{* *}}$ \\
DAt & $2.92 \pm 1.54^{\mathrm{a}^{*}}$ & $0.26 \pm 0.01^{\mathrm{a}^{* *}}$ \\
DH1 & $5.43 \pm 1.76$ & $0.28 \pm 0.04^{\mathrm{a}^{* *}}$ \\
DH2 & $6.05 \pm 4.19^{\mathrm{b}^{*}}$ & $0.31 \pm 0.04^{\mathrm{b}^{*}, \mathrm{c}^{*}}$ \\
\hline
\end{tabular}

Data were analysed using a one-way analysis of variance (ANOVA). A Post Hoc comparison using the LSD test was used to test the significant difference between the groups. Values are given as mean \pm standard deviation of the mean. a:significantly different from control; ${ }^{\mathrm{b}}$ :significantly different from the HCD group. ${ }^{\mathrm{c}}$ : significantly different from DAt group ${ }^{*}: p<0.05 ;{ }^{* *}: p<0.01$. C: commercial pellet; $\mathrm{CH}$ : commercial pellet plus $0.6 \mathrm{~g} / \mathrm{kg} /$ day Trihoney; HCD: $1 \%$ cholesterol diet; DH1: $1 \%$ cholesterol diet plus $0.3 \mathrm{~g} / \mathrm{kg} /$ day Trihoney; DH2: $1 \%$ cholesterol diet plus $0.6 \mathrm{~g} / \mathrm{kg} /$ day Trihoney; DAt: $1 \%$ cholesterol diet plus 2 $\mathrm{mg} / \mathrm{kg} /$ day atorvastatin.

Effects of Hypercholesterolaemia, Trihoney, and Atorvastatin on Serum Follicle-stimulating Hormone and Luteinizing Hormone

Effects of hypercholesterolaemia, Trihoney, and atorvastatin on serum FSH and LH are given in Table II. There was no significant difference between the $\mathrm{CH}$ group and the control group in the serum levels of FSH and LH. A marked elevation in serum FSH was expressed by the HCD group compared to the control group $(p<0.001)$. Atorvastatin received group exhibited a significantly higher level of FSH than the control group $(p<0.01)$. There was no significant difference between the HCD group and the DAt group. The DH1 $(p<0.01)$ and DH2 $(p<0.05)$ demonstrated significantly higher levels of FSH compared to the control group. A significantly lower level of FSH was shown by DH2 compared to the HCD group $(p<0.05)$. There was no significant difference between DAt, DH1, and DH2. As per $\mathrm{LH}$, no significant difference was detected neither between the treatment groups and the control group nor among the treatment groups.
Table II: Effects of Hypercholesterolaemia, Trihoney, and Atorvastatin on Serum Follicle-stimulating Hormone and Luteinizing Hormone

\begin{tabular}{ccc}
\hline $\begin{array}{c}\text { Hormones } \\
\text { Groups }\end{array}$ & $\begin{array}{c}\text { FSH } \\
(\mathrm{mlU} / \mathrm{mL})\end{array}$ & $\begin{array}{c}\text { LH } \\
(\mathrm{mlU} / \mathrm{mL})\end{array}$ \\
\hline C & $5.54 \pm 0.28$ & $2.59 \pm 0.51$ \\
CH & $5.37 \pm 1.06$ & $2.52 \pm 0.77$ \\
HCD & $12.27 \pm 2.75^{\mathrm{a}^{* * *}}$ & $3.54 \pm 0.44$ \\
DAt & $9.72 \pm 1.95^{\mathrm{a}^{* *}}$ & $2.89 \pm 0.72$ \\
DH1 & $9.88 \pm 0.89^{\mathrm{a}^{* *}}$ & $3.02 \pm 1.29$ \\
DH2 & $8.81 \pm 2.52^{\mathrm{a}^{*}, \mathrm{~b}^{*}}$ & $2.98 \pm 0.69$ \\
\hline
\end{tabular}

Data were analysed using a one-way analysis of variance (ANOVA). A Post Hoc comparison using the LSD test was used to test the significant difference between the groups. Values are given as mean \pm standard deviation. a:significantly different from control; ${ }^{b}$ :significantly different from the HCD group. ${ }^{*}: p<0.05 ;{ }^{* *} p<0.01$; ${ }^{* * *}: \mathrm{p}<0.001$. C: commercial pellet; $\mathrm{CH}$ : commercial pellet plus $0.6 \mathrm{~g} / \mathrm{kg} /$ day Trihoney; $\mathrm{HCD}$ : $1 \%$ cholesterol diet; DH1: $1 \%$ cholesterol diet plus $0.3 \mathrm{~g} / \mathrm{kg} /$ day Trihoney; DH2: $1 \%$ cholesterol diet plus $0.6 \mathrm{~g} / \mathrm{kg} /$ day Trihoney; DAt: $1 \%$ cholesterol diet plus $2 \mathrm{mg} / \mathrm{kg} /$ day atorvastatin; FSH: follicle-stimulating hormone; LH: luteinizing hormone.

Effects of hypercholesterolaemia, Trihoney, and atorvastatin on fasting blood glucose, fasting serum insulin and HOMA-IR

Table III illustrates the results of fasting serum insulin, fasting blood glucose, and HOMA-IR. There was no significant difference neither between the treatment groups and the control group nor among the treatment groups in these parameters.

Table III: Effects of hypercholesterolaemia, Trihoney, and atorvastatin on fasting blood glucose, fasting serum insulin and HOMA-IR

\begin{tabular}{cccc}
\hline $\begin{array}{c}\text { Parameters } \\
\text { Groups }\end{array}$ & $\begin{array}{l}\text { Fasting } \\
\text { glucose } \\
\text { (mmol/L) }\end{array}$ & $\begin{array}{l}\text { Fasting } \\
\text { insulin } \\
\text { (mU/L) }\end{array}$ & HOMA-IR \\
\hline C & $4.80 \pm 0.92$ & $0.41 \pm 0.28$ & $0.09 \pm 0.06$ \\
CH & $4.90 \pm 1.16$ & $0.48 \pm 0.17$ & $0.10 \pm 0.04$ \\
HCD & $5.30 \pm 1.95$ & $0.51 \pm 0.29$ & $0.14 \pm 0.14$ \\
DAt & $6.03 \pm 1.12$ & $0.47 \pm 0.08$ & $0.12 \pm 0.02$ \\
DH1 & $5.75 \pm 2.21$ & $0.56 \pm 0.15$ & $0.15 \pm 0.06$ \\
DH2 & $6.79 \pm 1.25$ & $0.50 \pm 0.14$ & $0.15 \pm 0.06$
\end{tabular}

Data were analysed using a one-way analysis of variance (ANOVA). A Post Hoc comparison using Tukey HSD test was used to test the significant difference between the groups. Values are given as mean \pm standard deviation of the mean. C: commercial pellet; $\mathrm{CH}$ : commercial pellet plus $0.6 \mathrm{~g} / \mathrm{kg} /$ day Trihoney; HCD: $1 \%$ cholesterol diet; $\mathrm{DH} 1: 1 \%$ cholesterol diet plus $0.3 \mathrm{~g} / \mathrm{kg} /$ day Trihoney; DH2: $1 \%$ cholesterol diet plus $0.6 \mathrm{~g} / \mathrm{kg} /$ day Trihoney; DAt: $1 \%$ cholesterol diet plus $2 \mathrm{mg} / \mathrm{kg} /$ day atorvastatin. 
Effects of $1 \%$ cholesterol diet, Trihoney, and atorvastatin on serum pro-inflammatory cytokines

The effects of $1 \%$ cholesterol diet, Trihoney, and atorvastatin on the serum pro-inflammatory cytokines are given in Table IV. There was no significant difference in the serum pro-inflammatory cytokines between the $\mathrm{CH}$ group and the control group. The HCD group showed significantly higher levels of TNF- $a(p<0.05)$ and IL-1B $(p<0.001)$ than the control group with a non-significant increase in IL-6. Treatment with atorvastatin caused a significant reduction in the serum TNF- $a(p<0.01)$ and $I L-1 B$ $(p<0.01)$ when compared to the HCD group with $a$ non-significant reduction in IL-6.

Trihoney received groups showed significantly lower levels of serum TNF- $a(p<0.001)$ than the HCD group and control group $(p<0.05$ for $\mathrm{DH} 1$ and $p<0.01$ for $D H 2)$. The DH1 $(p<0.01)$ and DH2 $(p<0.05)$ were significantly lower than the HCD group in the serum IL-1B and IL-6 $(p<0.05)$. There was no significant difference among DAt, $\mathrm{DH} 1, \mathrm{DH} 2$, and the control group in the serum IL-1B and IL-6. No significant difference was found between Trihoney received groups and atorvastatin treated group in the serum TNF-a level.

Table IV: The effect of $1 \%$ cholesterol diet, Trihoney and atorvastatin on the serum pro-inflammatory cytokines

\begin{tabular}{|c|c|c|c|}
\hline $\begin{array}{l}\text { Parameters } \\
\text { Groups }\end{array}$ & $\begin{array}{l}\text { TNF-a } \\
\text { (pg/mL) }\end{array}$ & $\begin{array}{l}\text { IL-6 } \\
\text { (pg/mL) }\end{array}$ & $\begin{array}{l}\text { IL-1B } \\
(\mathrm{pg} / \mathrm{mL})\end{array}$ \\
\hline C & $\begin{array}{l}15.09 \pm \\
0.32\end{array}$ & $\begin{array}{l}6.37 \pm \\
0.68\end{array}$ & $\begin{array}{l}85.99 \pm \\
5.84\end{array}$ \\
\hline $\mathrm{CH}$ & $\begin{array}{l}14.22 \pm \\
0.24\end{array}$ & $\begin{array}{l}6.57 \pm \\
0.34\end{array}$ & $\begin{array}{l}83.08 \pm \\
10.42\end{array}$ \\
\hline HCD & $\begin{array}{l}16.64 \pm \\
2.09^{a^{ \pm}}\end{array}$ & $\begin{array}{l}7.88 \pm \\
1.79\end{array}$ & $\begin{array}{l}167.07 \pm \\
13.36^{a^{* \pm x}}\end{array}$ \\
\hline DAt & $\begin{array}{l}13.91 \pm \\
0.18^{b^{ \pm \pi}}\end{array}$ & $\begin{array}{l}6.96 \pm \\
2.00\end{array}$ & $\begin{array}{l}96.15^{+} \\
23.90^{\text {b* }}\end{array}$ \\
\hline DH1 & $\begin{array}{l}13.511_{a^{ \pm}, b^{* \star *}} \\
0.08^{-1}\end{array}$ & $\begin{array}{l}5.96+ \\
0.47^{b^{*}}\end{array}$ & $\begin{array}{l}115.77_{+}^{+} \\
43.85^{\mathrm{b}^{\text {स* }}}\end{array}$ \\
\hline $\mathrm{DH} 2$ & $\begin{array}{l}12.74^{ \pm} \\
1.37^{a^{* *}, b^{* * *}}\end{array}$ & $\begin{array}{l}5.911^{ \pm} \\
0.41^{\mathrm{b}^{*}}\end{array}$ & $\begin{array}{l}130.311^{\frac{t}{2}} \\
28.05^{b^{*}}\end{array}$ \\
\hline
\end{tabular}

Data were analysed using a one-way analysis of variance (ANOVA). A Post Hoc comparison using the LSD test was used to test the significant difference between the groups. Values are given as mean \pm standard deviation of the mean. a:significantly different from control; ${ }^{b}$ : significantly different from the HCD group. ${ }^{*}: p<0.05 ;{ }^{* *}$ : $\mathrm{p}<0.01 ;{ }^{* * *}: \mathrm{p}<0.001$. C: commercial pellet; $\mathrm{CH}$ : commercial pellet plus $0.6 \mathrm{~g} / \mathrm{kg} /$ day Trihoney; HCD: $1 \%$ cholesterol diet; $\mathrm{DH} 1: 1 \%$ cholesterol diet plus $0.3 \mathrm{~g} / \mathrm{kg} /$ day Trihoney; DH2: $1 \%$ cholesterol diet plus $0.6 \mathrm{~g} / \mathrm{kg} /$ day Trihoney; DAt: $1 \%$ cholesterol diet plus $2 \mathrm{mg} / \mathrm{kg} /$ day atorvastatin; IL: interleukin; TNF-a: tumour necrosis factor-alpha.

\section{DISCUSSION}

In this study, Trihoney particularly at the dose of $0.6 \mathrm{~g} / \mathrm{kg} /$ day improved serum and intra-testicular testosterone, serum FSH, and serum proinflammatory cytokines. Treatment with atorvastatin improved serum pro-inflammatory cytokines but did not counteract the impact of hypercholesterolaemia on the reproductive hormones. Feeding of rabbits with a $1 \%$ cholesterol diet either alone or in combination with Trihoney or atorvastatin did not affect the levels of fasting serum insulin, fasting blood glucose, and HOMA-IR.

Gonadotropin-releasing hormone, FSH, LH, and testosterone are the hormones of the hypothalamic-pituitary-testicular axis. They are the main regulatory hormones of sperm production. ${ }^{24}$ Disturbance of this tightly regulated axis disrupts the normal physiology, metabolism and bioenergetics capacity of testicular tissue with a subsequent impairment of male fertility. ${ }^{25}$

In this study, the reduction in serum testosterone coupled with an elevation of FSH indicates that a testicular dysfunction (primary testicular failure) was induced by hypercholesterolaemia. ${ }^{26}$ Hypercholesterolaemia affects testicular structure and function, Sertoli and Leydig cells secretory functions, impairs steroid hormones biosynthesis and disrupts hypothalamic-pituitary-gonadal axis. ${ }^{27}$ Numerous studies have been conducted to investigate the effects of the high-energy diet and hypercholesterolaemia/hyperlipidaemia on male reproductive hormones. Zarei et al. (2014) ${ }^{7}$ reported that feeding of rats with a $2 \%$ cholesterol diet for 3 weeks significantly reduced serum FSH with no significant change in the serum testosterone and $\mathrm{LH}$. Alzubaidi \& Diwan (2013) ${ }^{30}$ revealed that feeding of rats with a $1.5 \%$ cholesterol diet for 4 weeks caused a severe reduction in serum testosterone, $\mathrm{FSH}$, and LH. Induction of hypercholesterolaemia, accompanied by hypertriglyceridaemia and obesity, in rabbits in a previous study produced a significant increase in plasma testosterone and FSH with a slight increase in $\mathrm{LH}$ and a reduction in intra-testicular testosterone. ${ }^{5}$ Rato et al. $(2013)^{4}$ demonstrated that supplementation of a high-energy diet containing cholesterol to rats resulted in a reduction of serum and testicular testosterone. The hormonal disturbances induced by hypercholesterolaemia in the 
current study are likely caused by its effect on the testicular tissue rather than through an effect on the hypothalamus or pituitary gland. The increase in gonadotropin (FSH and to a less extent $\mathrm{LH}$ ) is logically explained by the reduction in the serum testosterone which disrupts the feedback inhibitory mechanism on these hormones. ${ }^{7}$ The increase in FSH can also be explained by impaired production of inhibin B from Sertoli cells due to testicular dysfunction. ${ }^{28}$ Reduced serum testosterone and/or elevated serum FSH is indicative of impaired spermatogenesis and compromised fertility. ${ }^{28,29}$ Additionally, the reduction in intra-testicular testosterone in the present study would have a detrimental effect on spermatogenesis as intra-testicular testosterone is vital for the maintenance of spermatogenesis. ${ }^{2}$ The other possible mechanism of current hormonal disturbance is the elevation of serum pro-inflammatory cytokines by the administration of high-cholesterol diet. Overproduction of IL-1, IL-6, and TNF-a harms the male fertility through inhibition of steroidogenesis. ${ }^{31-}$ 33 Systemic inflammation can cause male infertility through the reduction of androgen production with subsequent disruption of spermatogenesis. ${ }^{34}$ Acute elevation of circulating IL-6 in healthy male volunteers through the injection of recombinant human IL-6 (rHulL-6) induced prolonged reduction in testosterone secretion. As no effect was observed on the LH level, it was speculated that IL-6 might induce testicular resistance to $\mathrm{LH}$ effect or suppress testosterone production by Leydig cells. ${ }^{33} \mathrm{~A}$ randomized controlled study showed that exposure to even minimal inflammatory stress through injection of interleukins reduced serum testosterone and amplified testosterone's negative feedback inhibition of $\mathrm{LH}^{35}$ To further support this relationship, IL-1B was found to be a potent down regulator of $\mathrm{LH}$ through a direct effect on the anterior pituitary gland during an inflammatory challenge in an ex vivo study. $^{36}$ In the current study, as there was a reduction in the testosterone with no significant changes in $\mathrm{LH}$, it could be that the inflammatory cytokines induced a testicular resistance to $\mathrm{LH}$ or suppressed testosterone production by Leydig cells as suggested previously. ${ }^{33}$

Treatment of rabbits with atorvastatin improved serum pro-inflammatory cytokines but did not counteract the impact of hypercholesterolaemia on the reproductive hormones. The reduction of serum testosterone with atorvastatin was reported in animal and human studies. ${ }^{37,38}$ Atorvastatin was one among other statins that were reported to reduce libido in men. Serum testosterone analysis of some of those reported cases revealed a significant reduction that regained to normal after statin withdrawal. ${ }^{39}$ Atorvastatin was suggested as one of the statins that might induce primary hypogonadism even at low dose. ${ }^{40}$ In a meta-analysis of randomized controlled trials, statins reduced testosterone level which was suggested to be through the reduction of cholesterol, the substrate of testosterone biosynthesis, or through inhibition of steps of steroidogenesis process. ${ }^{41}$ It could also be through inhibition of de novo synthesis of cholesterol in Leydig cells. ${ }^{39}$ This may explain the inability of atorvastatin to improve testosterone and subsequently FSH in the current study.

Supplementation of Trihoney particularly at the dose of $0.6 \mathrm{~g} / \mathrm{kg} /$ day improved serum pro-inflammatory cytokines, serum and intra-testicular testosterone, and serum FSH. This hormonal improvement is probably due to the effect of Trihoney on testicular tissue. The improvement of testicular tissue increases testosterone production which, in turn, decreases $\mathrm{FSH}$ through the negative feedback mechanism. Improvement of testicular tissue can also increase inhibin B secretion which reduces FSH. The hormonal improvement could also be through the anti-inflammatory mechanism of Trihoney that reduced serum inflammatory biomarkers with a subsequent elevation in serum testosterone and reduction of $\mathrm{FSH}$ through the negative feedback mechanism of testosterone. The effect of honey on male reproductive hormones has been investigated in various studies but this is the first study attempts to determine the effect of honey on male reproductive hormonal disturbances induced by hypercholesterolaemia. Oyelowo et al. (2014) ${ }^{9}$ reported that consumption of honey increased testosterone and reduced $\mathrm{FSH}$ and $\mathrm{LH}$ in rats fed with normal diet and rats received high sucrose solution. The beneficial effect of honey in increasing low serum testosterone, and reducing elevated serum FSH and LH was detected in noise-exposed rats. ${ }^{8}$ Supplementation of honey to cigarette smokeexposed rats, normal and diabetic rats improved serum testosterone without significant changes in serum FSH and LH. The improvement of serum testosterone was attributed to the local effect of honey on testicular tissue. ${ }^{42,43}$ Supplementation of honey for 12 weeks did not affect serum testosterone, FSH and $\mathrm{LH}$ in oligospermia men. ${ }^{44}$ 
As per serum insulin and HOMA-IR, there are controversies about the significance and strength of the association between insulin and testosterone. Among men with low testosterone, some were found to have low while others have high insulin concentrations. ${ }^{45}$ Insulin is deemed to have a regulatory role on serum testosterone concentration in men. Acute hyperinsulinaemia increased serum testosterone levels whereas, insulin suppression reduced testosterone in normal weight and obese individuals. $^{46,47}$

Insulin is abundant in the central nervous system. The absence of its signaling in the hypothalamus disrupts the process of steroidogenesis through inhibition of Leydig cell development. ${ }^{48}$ It has been suggested that insulin resistance could be a common underlying mechanism for both hypogonadisms and type 2 diabetes. ${ }^{49}$ The reduction in testosterone concentration in this study cannot be explained by a disturbance in insulin concentration and sensitivity as the concentration and HOMA-IR were comparable among all of the groups.

\section{CONCLUSION}

Trihoney particularly at the dose of $0.6 \mathrm{~g} / \mathrm{kg} /$ day significantly attenuated the detrimental effects of hypercholesterolaemia on male reproductive hormones. This indicates the potential health benefit of Trihoney to be used as a prophylactic agent to protect against hypercholesterolaemia-induced disruption of the male reproductive axis. The beneficial effect of Trihoney is most probably through a local effect on testicular tissue rather than on central regulatory mechanisms of male reproductive hormones. The second possible mechanism is the anti-inflammatory activity of Trihoney that reduced serum pro-inflammatory cytokines with a subsequent elevation in serum testosterone and reduction of $\mathrm{FSH}$. Atorvastatin treatment did not show an improvement in the reproductive hormones.

Finally, the effects of hypercholesterolaemia, Trihoney, and atorvastatin on the male reproductive axis did not mediate through insulin concentration or insulin resistance as their results were compared among the groups.

\section{CONFLICT OF INTEREST}

The authors declared no conflict of interest

\section{ACKNOWLEDGMENT}

This research was funded by the International Islamic University Malaysia (IIUM) Research Acculturation Grant Scheme (IRAGS) from IIUM Research Management Centre (grant number: IRAGS18-0430044).

\section{REFERENCES}

1. Sanaz A, Amirreza T, Solmaz R, Keyvan A, Elham Y. Cadmium and male infertility. J Infertil Reprod Biol. 2014;2(2):62-9.

2. Ring J, Lwin A, Köhler T. Current medical management of endocrine-related male infertility. Asian J Androl. 2016;18(3):357-63.

3. Comninos AN, Jayasena CN, Dhillo WS. The relationship between gut and adipose hormones, and reproduction. Hum Reprod Update. 2014;20 (2):153-74.

4. Rato L, Alves MG, Dias TR, Lopes G, Cavaco JE, Socorro $S$, et al. High-energy diets may induce a pre-diabetic state altering testicular glycolytic metabolic profile and male reproductive parameters. Andrology. 2013;2013(1):495-504.

5. Soltani Y, Aklil B, Mokrani Z, Hamouli Z, F HB. Effects of diet induced obesity on the gonadal axis in the male rabbit: impact of leptin. USTHB -FBS-4th Int Congr Popul Anim Communities “Dynamics Biodivers Terr Aquat Ecosyst - Alger. 2013;478-87.

6. Mu Y, Yan W, Yin T, Zhang Y, Li J, Yang J. Dietinduced obesity impairs spermatogenesis: a potential role for autophagy. Sci Rep. 2017;7 (43475):1-13.

7. Zarei A, Ashtiyani SC, Vaezi GH. A study on the effects of the hydroalcholic extract of the aerial parts of Alhagi camelorum on prolactin and pituitary-gonadal activity in rats with hypercholesterolemia. Arch Ital di Urol e Androl. 2014;86(3):188-92.

8. Kenani M, Rajabzadeh A, Saki G, Khodadadi A, Sarkaki A, Jafai A, et al. A Survey of the Relationship Between Noised Pollution, Honey and Vitamin E and Plasma Level of Blood Sexual Hormones in Noise-Exposed Rats. Jentashapir J Heal Res. 2015;6(1):1-5.

9. Oyelowo OT, Adekunbi DA, Dada KA. Protective Role of Nigerian Honey on Sperm indices and Testis in Sucrose-Fed Rats. Bangladesh J Med Sci. 2014;13(2):180-9.

10. Mohamed ZBH, Ibrahim M Bin, Alfarisi $\mathrm{HAH}$, 
Abdul Wahab AY, Abd Fuaat A, Mohamad CAC. Trihoney ameliorates hypercholesterolemiainduced epididymal histopathological changes in male rabbits. AsPac J Mol Biol Biotechnol. 2020;28(1):90-100.

11. Reagan-Shaw S, Nihal M, Ahmad N. Dose translation from animal to human studies revisited. FASEB J. 2007;22(3):659-61.

12. Du B, Xu G, Cao H, Cui W, Lin S, Liu Y, et al. Effects of atorvastatin on expression of ICAM-1 in atherosclerotic rabbits. J Cardiovasc Med. 2013;14(2):120-6.

13. Song $X$, Liu $H$, Wang $X$, Li Z, Huang $C$. Atorvastatin combined with poly-unsaturated fatty acid confers better improvement of dyslipidemia and endothelium function. Lipids Health Dis. 2014;13(186):1-5.

14. Zhao X-H, Qiu J-H, Cai W-Q, Li S, Li W. Preparation of infertile male rabbits by local electron beam irradiation for intratesticular transplantation of autologous bone marrow stem cells. Acta Cir Bras. 2013;28(2):148-53.

15. Leary S, Underwood W, Anthony R, Cartner S, Corey D, Grandin T, et al. AVMA Guidelines for the Euthanasia of Animals. 2013 Editi.

Schaumburg: American Veterinary Medical Association; 2013. 1-102 p.

16. Galaly SR, Hozayen WG, Amin KA, Ramadan SM. Effects of Orlistat and herbal mixture extract on brain, testes functions and oxidative stress biomarkers in a rat model of high fat diet. BeniSuef Univ J Basic Appl Sci. 2014;3(2):93-105.

17. Yan L, Bai X, Fang Z, Che L, Xu S, Wu D. Effect of different dietary omega-3/omega-6 fatty acid ratios on reproduction in male rats. Lipids Health Dis. 2013;12(33):1-9.

18. Sukardi S, Yaakub H, Ganabadi S, Ms P. Serum Testosterone Levels and Body Weight Gain of Male Rabbits Fed with Morinda citrifolia Fruit Juice. Mal J Nutr. 2005;11(1):59-68.

19. Matthews DR, Hosker JP, Rudenski AS, Naylor BA, Treacher DF, Turner RC. Homeostasis model assessment: insulin resistance and $\square$ ?-cell function from fasting plasma glucose and insulin concentrations in man. Diabetologia. 1985;28 (7):412-9.

20. Graham J. Homogenization of Mammalian Tissues. Sci World J. 2002;2:1626-9.

21. Ilbey YO, Ozbek E, Simsek A, Cekmen M, Otunctemur A, Somay A. Chemoprotective Effect of a Nuclear Factor-B Inhibitor, Pyrrolidine Dithiocarbamate, Against Cisplatin-
Induced Testicular Damage in Rats. J Androl. 2009;30(5):505-14.

22. Mohamed M, Sulaiman SA, Jaafar H, Sirajudeen KNS. Antioxidant Protective Effect of Honey in Cigarette Smoke-Induced Testicular Damage in Rats. Int J Mol Sci. 2011;12(9):5508-21.

23. Wagner IV, Klöting N, Atanassova N, Savchuk I, Spröte C, Kiess W, et al. Prepubertal onset of obesity negatively impacts on testicular steroidogenesis in rats. Mol Cell Endocrinol. 2016;437:154-62.

24. Esteves SC, Miyaoka R, Agarwal A. An update on the clinical assessment of the infertile male. Clinics. 2011;66(4):691-700.

25. Rato L, Alves MG, Cavaco JE, Oliveira PF. Highenergy diets: a threat for male fertility? Obes Rev. 2014;15(12):996-1007.

26. Lindsay TJ, Vitrikas KR. Evaluation and treatment of infertility. Am Fam Physician. 2015;91(5):308-14.

27. Pushpendra A, GC J. Hyper-Lipidemia and Male Fertility: A Critical Review of Literature. Andrology-Open Access. 2015;04(02):1-12.

28. Ergün A, Köse SK, Aydos K, Ata A, Avci A. Correlation of Seminal Parameters with Serum Lipid Profile and Sex Hormones. Arch Androl. 2007;53(1):21-3.

29. Jarow J, Sigman M, Kolettis PN, Lipshultz LR, Mcclure RD, Nangia AK, et al. The Optimal Evaluation of the Infertile Maler: AUA Best Practice Statement. American Urological Association Education and Research, Inc. 2010. p. 1-38.

30. Alzubaidi NAK, Diwan MA Al. The Effect of Taurine on Reproductive Efficiency in Male Rats Fed High Cholesterol Diet. Bas.j.vetRes. 2013;12(1):30-40.

31. Syriou V, Papanikolaou D, Kozyraki A, Goulis DG. Cytokines and male infertility. Eur Cytokine Netw. 2018;29(3):73-82.

32. Huston JC. Physiologic Interactions Between Macrophages and Leydig Cells. Exp Bioi Med. 2006;231(1):1-7.

33. Tsigos C, Papanicolaou DA, Kyrou I, Raptis SA, Chrousos GP. Dose-Dependent Effects of Recombinant Human Interleukin-6 on the Pituitary-Testicular Axis. J Interf Cytokine Res. 1999;19(11):1271-6.

34. Hedger MP, Meinhardt A. Cytokines and the immune-testicular axis. J Reprod Immunol. 2003;58(1):1-26.

35. Veldhuis J, Yang R, Roelfsema F, Takahashi P. 
Proinflammatory cytokine infusion attenuates Lh's feedforward on testosterone secretion: Modulation by age. J Clin Endocrinol Metab. 2016;101(2):539-49.

36. Herman AP, Krawczyńska A, Bochenek J, Dobek E, Herman A, Tomaszewska-Zaremba D. LPSinduced inflammation potentiates the IL-1 B mediated reduction of $\mathrm{LH}$ secretion from the anterior pituitary explants. Clin Dev Immunol. 2013;2013:1-7.

37. Bustan A, Jawad A. The Effect of Two Types of Statins (Rosuvastatin and Atorvastatin) on the Fertility of Male and Female Mice. Br J Med Med Res. 2017;19(12):1-11.

38. Kanat $M$, Serin E, Tunckale A, Yildiz O, Sahin S, Bolayirli $\mathrm{M}$, et al. A multi-center, open label, crossover designed prospective study evaluating the effects of lipid lowering treatment on steroid synthesis in patients with type 2 diabetes (MODEST Study). J Endocrinol Invest. 2009;32(10):852-6.

39. de Graaf L, Brouwers AHPM, Diemont WL. Is decreased libido associated with the use of HMG -CoA-reductase inhibitors? Br J Clin Pharmacol. 2004;58(3):326-8.

40. Corona G, Boddi V, Balercia G, Rastrelli G, De Vita G, Sforza A, et al. The Effect of Statin Therapy on Testosterone Levels in Subjects Consulting for Erectile Dysfunction. J Sex Med. 2010;7(4):1547-56.

41. Schooling CM, Au Yeung SL, Freeman G, Cowling BJ. The effect of statins on testosterone in men and women, a systematic review and metaanalysis of randomized controlled trials. BMC Med. 2013;11(57):1-9.

42. Mahaneem $M$, Sulaiman $S A$, Jaafar $H$, Nainamohamed K, Sirajudeen S, Ismail ZIM, et al. Effect of honey on testicular functions in rats exposed to cigarette smoke. J ApiProduct ApiMedical Sci. 2011;3(1):12-7.

43. Michael M, Anyakudo C, Balogun AJ, Adeniyi MO. Beneficial Effects of Honey-Based Diet on Glycemic Control and Reproductive Potential in Diabetic Rats. World J Nutr Heal. 2015;3(2):416.

44. Ismail SB, Bakar MB, Nik Hussain NH, Norhayati $M N$, Sulaiman SA, Jaafar $\mathrm{H}$, et al. Comparison on the Effects and Safety of Tualang Honey and Tribestan in Sperm Parameters, Erectile Function, and Hormonal Profiles among Oligospermic Males. Evidence-Based Complement Altern Med. 2014;2014:1-10.
45. Gevi F, Fanelli G, Zolla L. Metabolic patterns in insulin-resistant male hypogonadism article. Cell Death Dis. 2018;9(617):1-11.

46. Pasquali R, Macor C, Vicennati V, De lasio FR, Mesini $P$, Boschi $S$, et al. Effects of acute hyperinsulinemia on testosterone serum concentrations in adult obese and normalweight men. Metabolism. 1997;46(5):526-9.

47. Pasquali R, Casimirri F, De lasio R, Mesini $P$, Boschi $S$, Chierici R, et al. Insulin regulates testosterone and sex hormone-binding globulin concentrations in adult normal weight and obese men. J Clin Endocrinol Metab. 1995;80 (2):654-8.

48. Kamalrudin A, Jasamai $M$, Mat Noor $M$. Ameliorative effect of Moringa oleifera fruit extract on reproductive parameters in diabeticinduced male rats. Pharmacogn J. 2018;10 (6):S54-8.

49. Kasturi SS, Tannir J, Brannigan RE. The Metabolic Syndrome and Male Infertility. J Androl. 2008;29(3):251-9. 